\title{
IdeAs
}

Idées d'Amériques

$14 \mid 2019$

Populismes dans les Amériques

\section{Populism in the American West: An Enduring and Evolving Trend}

Le populisme dans l'Ouest américain : permanence et évolution d'une tendance

El populismo en el oeste de Estados Unidos : permanencia y evolución de una tendencia

Nathalie Massip

\section{OpenEdition}

\section{Journals}

\section{Electronic version}

URL: http://journals.openedition.org/ideas/5793

DOI: 10.4000/ideas.5793

ISSN: 1950-5701

\section{Publisher}

Institut des Amériques

\section{Electronic reference}

Nathalie Massip, «Populism in the American West: An Enduring and Evolving Trend », IdeAs [Online] 14 | 2019, Online since 01 October 2019, connection on 10 December 2020. URL : http:// journals.openedition.org/ideas/5793 ; DOI : https://doi.org/10.4000/ideas.5793

This text was automatically generated on 10 December 2020.

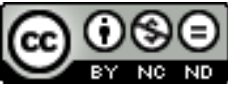

IdeAs - Idées d'Amériques est mis à disposition selon les termes de la licence Creative Commons Attribution - Pas d'Utilisation Commerciale - Pas de Modification 4.0 International. 


\title{
Populism in the American West: An Enduring and Evolving Trend
}

\author{
Le populisme dans l'Ouest américain : permanence et évolution d'une tendance \\ El populismo en el oeste de Estados Unidos : permanencia y evolución de una \\ tendencia
}

Nathalie Massip

\section{Introduction}

1 When members of the Kansas Farmers Alliance coined the word "populist" to refer to the political ideas that they were discussing, in May 1891 (Judis, J., 2016: 21), they could not predict the fate of the neologism. Little did they know that scholars and journalists would have a hard time agreeing on a consensual definition well into the $21^{\text {st }}$ century, or that it would be as topical a term in the 2010s as it was in the 1890s. Indeed, a survey of newspapers headlines and articles of the last fifteen or so years would certainly give

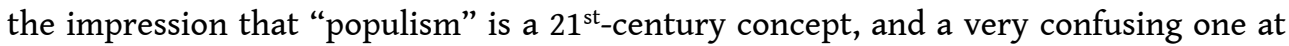
that. While the word usually refers to "clientelism and economic mismanagement" when applied to Latin American countries, it denotes "anti-immigration and xenophobia" when studied in a European context (Mudde, C., and C. R. Kaltwasser, 2017: 2). In the United States, the word seems to be as flexible as can be, covering the whole political spectrum, from Bernie Sanders to Donald Trump.

In The Populist Persuasion, historian Michael Kazin defines populism as "a language whose speakers conceive of ordinary people as a noble assemblage not bounded narrowly by class, view their elite opponents as self-serving and undemocratic, and seek to mobilize the former against the latter" (Kazin, M., 1995: 1). More recently, Cas Mudde and Cristóbal Kaltwasser have depicted populism as "a thin-centered ideology that considers society to be ultimately separated into two homogeneous and antagonistic camps, 'the pure people' versus 'the corrupt elite,' and which argues that politics should be an expression of the volonté générale (general will) of the people" 
(Mudde, C., and C. R. Kaltwasser, 2017: 6). As for John Judis, he considers that "populists have defined politics in 'us vs. them' terms-as struggles of the people against the establishment based on issues and demands that the latter had been sidestepping" (Judis, J., 2016: 21). Bearing in mind these characteristics-the people, the elite, the resentment of the latter by the former-it is my contention that a populist strain has characterized the American West since the late $19^{\text {th }}$ century.

This premise echoes Kazin's claim that populism has always infused American politics, even though the present study focuses on the American West specifically (Kazin, M., 1995). Yet, pinpointing particular periods in order to highlight a populist strain in the US West should not be seen as a suggestion that these outbursts bear equal historical significance. As historian Charles Postel has argued, late- $19^{\text {th }}$ century Populism stands out for a variety of reasons: "It was a particular constellation of ideas, circulating within a specific coalition of reform, and set in motion within a distinct historical context" (Postel, C., 2007: 22). In other words, this early instance was more than a language or an ideology. This explains why historians have devoted whole monographs -if not careers-to the Populist movement of the late $19^{\text {th }}$ century, from John D. Hicks to Richard Hofstadter, Lawrence Goodwyn and Charles Postel, while analyses of the concept of "populism" in a diachronic and/or global perspective systematically include detailed considerations on the movement, from Kazin's Populist Persuasion to Judis' Populist Explosion. It is because the very concept of "Populism" with a capital $P$ was born in the US West and South that it is used here as a point of reference. ${ }^{1}$

One can observe three major outbursts of populism in the history of the American West. The very first occurrence, which took place in the late $19^{\text {th }}$ century, gave "Populism" its name. Faced with a major economic crisis, farmers from the Great Plains and the South formed Alliances, then united with members of the Knights of Labor, and created the People's party in time for the 1892 presidential election. The party did not last very long, but the reforms of the late $19^{\text {th }}$ and early $20^{\text {th }}$ centuries attest to the impact of this first populist movement. A second populist outburst took place in the late 1970s. The purpose of the so-called Sagebrush Rebellion was to force the federal government to turn over control and management of public lands to the states. Rural westerners, allied with western politicians, resented and denounced the overwhelming presence of the federal government in the region; for a couple of years, they used legislative and political tools to reach their goal, but to no avail. The third and most recent populist explosion seems to have risen from the ashes of the Sagebrush Rebellion, though the occupation of the Malheur National Wildlife Refuge (OR) in early 2016 by the "People for Constitutional Freedom" attests to a radicalization of western populism.

5 This periodization is artificial by force; one could argue that the Sagebrush Rebellion started long before $1979,{ }^{2}$ and/or that the current manifestation of populism in the West is but another episode of the "long" Sagebrush Rebellion. Yet, the premise of this article is that populism in the American West has been expressed in outbursts, and that the Populist movement of the late $19^{\text {th }}$ century, the Sagebrush Rebellion of 1979-1982, and the agitation of the mid-2010s amount to such fits. As I intend to show in this article, these three periods of western agitation share the major characteristics that define "populism." Yet, they also diverge in ways that are as significant as their common denominators are. First, "populism" would not exist were it not for "the people," and a key element of these movements is their reliance on the sovereignty of 
the people. However, the latter being as vague and elusive a concept as can be, it will be necessary to thoroughly assess who gets to be included and who does not. Finally, because the latest outburst of western populism significantly differs from the first in that it is "triadic [...], [looking] upward, but also down upon an out group" (Judis, J., 2016: 14), a transformation from left-wing to right-wing populism can be observed. Evaluating the goals and achievements of these movements will provide a better understanding of this evolution.

\section{The sovereignty of the "people"}

6 At the heart of these episodes of western agitation lie the people. If one considers, as Kazin does, that populism is "a language" (Kazin, M., 1995: 1), then the celebration of the people constitutes the backbone of its rhetoric. The name given to the first populist party attests to this centrality. Created in 1892, "the People's Party of America" gathered members of various Farmers' Alliances and of the Knights of Labor. It was born out of a rejection of traditional political parties, when "the people [decided to turn] to independent political action," thus forming "a mass democratic movement" (Goodwyn, L., 1978: xxi).

7 The founding document of the party, known as the Omaha Platform, emphasizes the sovereignty of the people, since the purpose of the movement was "to restore the government of the Republic to the hands of 'the plain people', with which class it originated" (National People's Party Platform, 1892). Adopted on July 4, 1892, the party's platform paid tribute to George Washington, "the grand general and chief who established our independence," asserted its loyalty to the "National Constitution," and echoed Abraham Lincoln's plea for a "government of the people, by the people, for the people" (Lincoln, A., 1863):

We believe that the power of government-in other words, of the people-should be expanded [...] as rapidly and as far as the good sense of an intelligent people and the teachings of experience shall justify, to the end that oppression, injustice, and poverty shall eventually cease in the land (National People's Party Platform, 1892).

If the Sagebrush Rebellion of the late 1970s-early 1980s is remembered for the various state laws passed in order to take hold of land managed by the Bureau of Land Management, the movement was powered by ranchers (Boly, W., 1980: 19). Its most vocal artisan was Nevada rancher Dean Rhoads, who had previously been president of the Public Lands Council, an association of western ranchers grazing their herds on public lands. As a member of the Nevada State Assembly, Rhoads introduced Assembly Bill 413-which would then be nicknamed "the Sagebrush Rebellion bill"3-in February 1979. Signed by Republican Governor Robert List, the bill forcefully denounced federal ownership and control of lands in Nevada as "[working] a severe, continuous and debilitating hardship upon the people of the State of Nevada" (Nevada Assembly Bill 413, 1979: 1). It created the Nevada lands commission, whose goal was to "manage the public lands of the state in an orderly and official manner" (ibid., 3). Just as the members of the People's party of America spoke "in the name and on behalf of the people of this country" (National People's Party Platform, 1892), the commission was created in order to represent "the people of the State of Nevada" (Nevada Assembly Bill 413, 1979: 1). Nevada accordingly purported to appropriate no less than 48 million acres of public lands, which amounted to 79\% of the state (Cawley, R., 1993: 1). In its wake, Arizona, New Mexico, Utah, Washington, and Wyoming passed the same type of 
legislation, while in August 1979, western Senator Orrin Hatch introduced S.1680 in Congress. Known as the "Western Lands Distribution and Regional Equalization Act" the bill was meant to confirm the states' titles. According to Senator Hatch, the bill was designed to defend and protect the interests of the people of Utah, his home state, but, also, of "all Americans" (Hatch, O., 1979: 4A).

A similar claim was made by Ammon Bundy as he strove to justify the armed standoff that took place on his father's ranch in 2014. On March 27, western rancher Ammon Bundy informed the Bureau of Land Management agents that he would do "whatever it takes" to prevent the BLM from seizing his father's cattle. The court-ordered roundup culminated a 21-year legal dispute opposing Ammon's father, Nevada rancher Cliven Bundy, and the United States Bureau of Land Management, as a result of Bundy's refusal to pay the fees required to graze his herds on federal land. On April 12, Bundy's threat escalated into an armed standoff opposing Bundy's supporters and BLM agents. Largely outnumbered and outgunned, the latter had to retreat and release the cattle, to shouts of Ammon that "the West has now been won!" Reflecting on the episode, Ammon Bundy declared: "As important as it is for a man to fight for his ranch and his livelihood, this is much bigger than that. This is the American people fighting for their freedoms" (audio recording in Johnson, J., Feb. 21, 2017). Despite the fact that his father owed more than 1 million dollars in grazing fees to the BLM and, therefore, to the federal government, Bundy characterized the armed standoff that took place on his father's ranch as an act of civil disobedience that was performed in the name of the American people as a whole. Similarly, when the "People for Constitutional Freedom" occupied the Malheur National Wildlife Refuge in Harney County, Oregon, in early 2016, they claimed to do so "because the people have been abused long enough" (Bundy Ranch, Jan. 2, 2016). Requesting that all federal land in Harney County be put under local control, leader of the movement Ammon Bundy once again put forward the "people" to justify the occupation. According to him, the occupiers' goal was "to assist the people of Harney County [...] in claiming their rights. [...] Our end goal is to see the people of Harney County back using their rights again, under their claim, not as permittees, not as a privilege, but as a right" ("Militant leader explains...," Jan. 3, 2016). Ironically, the refuge, which the occupiers referred to as "the people's facility, owned by the people" (Bundy Ranch, Jan. 2, 2016), remained closed off for several weeks due to the occupation.

10 What the Bundys and their friends were protesting and denouncing in 2014 and, again, in 2016, was the presence of the federal government in the American West, mostly through the Bureau of Land Management. In the leader's words, the "people" were the victims of the federal government:

We have the EPA that is taking properties away from American people, they're restricting full industries, putting full states and counties into economic depression. We have a slew of other federal agencies that are doing the exact same thing. And they're doing it by controlling the land and resources because they know where wealth generates from. Wealth generates from the earth, from the land and the resources. [...] The American people have to basically beg them for whatever they give them (ibid.).

11 The same sense of victimization characterized the rhetoric of the "Sagebrush Rebels" of the late 1970s-early 1980s. The Bureau of Land Management was already depicted as the villain: "their decisions are so senseless they seem almost deliberate-part of a plan to get rid of the ranchers altogether and leave the whole West to the coyotes" (Boly, W., 
1980: 21). Ranchers in the late 1970s resented "that perfidious absentee landlord on the Potomac" (ibid., 19) as much as they do today, and western politicians were no less critical of "Uncle Sam" and "Uncle's boys" (Hatch, O., 1979: 4A).

The target of the early populists, who created the People's Party, was not the federal government; on the contrary, Populists called for more government intervention in and control of the economy, demanding, for instance, a federal takeover of railroads. Yet, like the Sagebrush Rebels and today's proponents of land transfer, their rhetoric rested on the same opposition between "the pure people" and "the corrupt elite" which is at the heart of the definition of populism. In the late $19^{\text {th }}$ century, industrialists and capitalists, acting for and in the name of money, stood for the "corrupt elite":

capitalists, corporations, national banks, rings, trusts, watered stock, the demonetization of silver and the oppressions of the usurers may all be lost sight of. They propose to sacrifice our homes, lives, and children on the altar of mammon; to destroy the multitude in order to secure corruption funds from the millionaires (National People's Party Platform, 1892).

Ultimately, beyond this "us vs. them" rhetoric (Judis, J., 2016: 21), these three outbursts of populist anger reveal a deep-seated fear of social downgrading on the part of westerners. The preamble of the National People's Party Platform attests to the intensity of this fear. The document opens on a very bleak assessment of the context of the late $19^{\text {th }}$ century, describing "a nation brought to the verge of moral, political, and material ruin." From "corruption" to "demoralization," the first paragraph amounts to a litany of evils affecting American society, before concluding:

The fruits of the toil of millions are boldly stolen to build up colossal fortunes for a few, unprecedented in the history of mankind; and the possessors of those, in turn, despise the Republic and endanger liberty. From the same prolific womb of governmental injustice we breed the two great classes-tramps and millionaires (ibid.).

The rest of the preamble deplores the "grievous wrongs [that] have been inflicted upon the suffering people," denounces the plight of the "plundered people," and laments "the impoverishment of the producing class." Close to a century later, Sagebrush Rebels bemoaned the same social and economic difficulties, and accused the federal government of "[seeking] to put us in an economic freeze of no growth, no progress and no future" (Hatch, O., 1979: 4A). According to Ammon Bundy, the situation of $21^{\text {st }}$ century western ranchers has only gotten worse as a result of the federal presence in the American West:

[The people's] lands and [...] resources have been taken from them to the point where it's putting them literally in poverty. [...] The people cannot survive without their land and resources. [...] All comfort, all wealth, everything that we have as a people, that we use to live, to eat, to find comfort, comes from the earth. We cannot have the government restricting the use of that to the point where it puts us in poverty (Bundy Ranch, Jan. 2, 2016).

Even though the "us vs. them" rhetoric prevails in all three episodes of western anger, one would be hard pressed to make out a uniform and homogeneous group that would qualify as "the people." Therefore, it is important to take a closer look at these movements in order to determine who "the people" are. 


\section{The "people"-what people?}

16 These three episodes of western populism attest to Judis' statement that "[j] ust as there is no common ideology that defines populism, there is not one constituency that comprises 'the people"' (Judis, J., 2016: 15). The People's Party was a motley crowd, gathering mostly farmers, industrial workers, and members of reform movements. According to Charles Postel, the inaugurating conferences that took place in 1891-1892 were attended by very diverse groups that included "the Farmers' Alliance and Industrial Union, the National Farmers' Alliance, the Colored Farmers' Alliance, the Farmers' Mutual Benefit Association, the Knights of Labor, the Women's Alliance, [and] the Citizen's Alliance" among others (Postel, C., 2007: 12). Postel argues that "[the] combined membership of the Farmers' Alliance and kindred associations numbered in the millions" (ibid., 14), which gives an idea of the magnitude of the movement. The more diverse the group of "people," the more representative it is of the larger society, and the bigger its impact; yet, this diversity may also imply a lack of consensus. In the case of the late $19^{\text {th }}$-century Populist movement, though, its members were united in their quest for change, and "the spirit of reform encouraged the search for orthodoxy" (ibid.).

17 Even though it was born in the South and West of the United States, the first outburst of populism was truly national in scope. Until recently, though, historians have analyzed 1890s Populism along regional lines. While John Hicks saw the "Populist Revolt" as a Midwestern phenomenon, Lawrence Goodwyn focused on the Texas origins of the movement, and C. Vann Woodward looked further South in his biography of Georgia populist leader Tom Watson. Yet, put together, these analyses show the national scope of the movement, which "took root across a broad territory of cotton and wheat, staple crops and specialty crops, mining and railroads, white and black, rural and urban" (Postel, C., 2007: 14).

The broad, all-encompassing nature of the movement, as well as its geographical scope, sharply contrasts with the later versions of western populism. While the late-19 $9^{\text {th }}$ century Populism was "a social and political movement that touched millions of lives and spanned a continent" (ibid., 13), the Sagebrush Rebellion of the late 1970s was a much more circumscribed regional phenomenon, that nonetheless stirred up about a dozen states in the American West. The scope of the latest version of western populism is even smaller, since several western legislatures have decided not to follow Utah's lead in its 2012 request for land transfer. At the grassroots level, the protest and anger seem to come from rural islets, of which Cliven Bundy's "Bunkerville," in Nevada, seems to be the most conspicuous example.

Despite these differences in representativeness, the "people" whose interests need to be defended are defined in the same way in all three movements: they are the "producing classes." The second item of the Omaha Platform states the party's defense of those who actively contribute to the welfare of society: "Wealth belongs to him who creates it, and every dollar taken from industry without an equivalent is robbery." Not only do the leaders of the movement deplore the "impoverishment of the producing class," but they also insist that both farmers and industrial workers are united under the same banner: "The interests of rural and civil labor are the same; their enemies are identical" (National People's Party Platform, 1892). Whether addressing indebted Southern sharecroppers, Western farmers whose livelihoods depended on railroad companies, 
miners from the mountain West, Northeastern urban industrial workers, old-stock Americans, or newly-arrived immigrants, Populist leaders resorted to a rhetoric that managed to "generate a shared identity between different groups and facilitate their support for a common cause" (Mudde, C., and C. R. Kaltwasser, 2017: 9).

Less diverse in terms of membership and more limited geographically, the Sagebrush Rebellion nonetheless united potentially conflicting interests: ranching, mining, oil, coal, and timber industries all gathered around the fear that their very livelihoods were threatened by the environmental policies of the federal government. This fear was best expressed by Nevada rancher Dean Rhoads, when he declared to a congressional committee: "Not only do we have to contend with present management policies that restrict production, we must look ahead apprehensively to wilderness review, grazing environmental impact statements and more rules, regulations and restrictions" (quoted in Cawley, 1993: 4). As both a rancher and a member of the Nevada State Assembly, Rhoads embodied the peculiar coalition of natural resources industries, politicians (both local and state), and western citizens that the movement comprised.

Concerned that the Sagebrush Rebellion might be regarded as "an outburst motivated by economic self-interest" (Cawley, 1993: ix), some western politicians defended the rebels as citizens who simply wanted to have a say in the way they conducted their lives: "Everybody thinks that the Sagebrush Rebellion is just for the benefit of cattlemen. The basic concern is that people here have nothing to say about the large hunks of federally owned and managed lands" (Arizona State Senator Anne Lindeman quoted in "The Sagebrush Rebellion," Dec. 1, 1980). Similarly to the Omaha Platform, the rhetoric of the Sagebrush Rebellion emphasized the moral superiority of the "producing classes," whose work and intimate experience of the land they had lived on for generations granted them the legitimacy the federal bureaucracy lacked: "Who should own and manage our lands to assure maximum benefits for all Utahns and ultimately for all Americans? The people of Utah or the officious, oppressive agents of Washington's sprawling marching army of clerks and self-appointed experts?" (Hatch, O., 1979: 4A).

The episode also revealed a widening gap between rural and urban westerners: the increasingly urbanized population, which enjoyed the wide-open spaces and the recreational opportunities that the region offered, pushed for federal oversight and protection. The "rebellion," on the other hand, was meant to be an expression of rural westerners' resentment at federal rules and regulations that, to them, valued wilderness and the environment more than people. Not only did farmers, ranchers, miners, loggers, and hunters feel left out of the public debate, but they also claimed to be the best and only experts when it came to managing the land. Rhoads thus argued: "We feel we're probably the best environmentalists of all. [...] I think the people who really love that land and are gonna live there would take the best care of it" (quoted in Boly, W., 1980: 21).

23 A similar feeling animates the $21^{\text {st }}$-century movement to (re)claim the western lands. Its members maintain they are acting to protect the local economy, trying "to get the logger back to logging, the rancher back to ranching" (Ammon Bundy quoted in Boone, R., Jan. 6, 2016). Echoing late $19^{\text {th }}$-century populist discourse, the "pure people" (Mudde, C., and C. R. Kaltwasser, 2017: 6) are those who work the land and produce the goods needed for the welfare of society. Asked by a journalist what it would take for the "People for Constitutional Freedom" to put an end to their occupation of the Oregon 
Malheur National Wildlife Refuge, leader Ammon Bundy replied: "when the people of Harney County can use the land and resources without being put in fear and without being restricted to the point where it puts them out of business. Once they can use these lands as free men, then we will have accomplished what we've come to accomplish" (Bundy Ranch, Jan. 2, 2016). Like the Sagebrush Rebels of the late 1970s, Bundy and his supporters see the federal government as the enemy of the people, preventing them from making a decent living while caring for the environment. Ironically, the "people of Harney County," whom Bundy claimed to have thought out the occupation for, were not particularly thrilled by the gesture and the sudden media attention it triggered (Allen, J., and J. Urquhart, Jan. 4, 2016). His assertion that "[i]t might take a little bit for people to realize that, but we're here for them, we're here with them" (Bundy Ranch, Jan. 2, 2016) might even sound pathetic.

Most importantly, these statements beg the question of the nature of the "people" whom populists claim to be defending and/or speaking for, and of populists' ability to "mobilize [...] ordinary people [...] against [...] their elite opponents" (Kazin, M., 1995: 1). Despite local and occasional "forms of indigenous interracial activity" (Goodwyn, L., 1971: 1451), late $19^{\text {th }}$-century Populism was very selective. While the idea of progress was its main driving force, the overall movement also believed in white supremacy and separation of the races, seen as "essential for the modern development of both blacks and whites" (Postel, C., 2007: 176). Notwithstanding the promise of equality, "the color line held" (ibid.), in tune with the times, marked by Jim Crow laws, the disenfranchisement of black voters, and Chinese exclusion. The latter was called for by Populists, with firebrand leaders like Mary Lease warning of a "tide of Mongols" and Tom Watson depicting Chinese as "moral and social lepers" (quoted in ibid., 185). When dealing with populism, what the very elusive "people" excludes is at least as significant as what it includes.

In the case of the "People for Constitutional Freedom," the group's appeal to "the people" was fraught with contradictions. For example, the armed militants claimed that the 2016 occupation was motivated by the imprisonment of two local ranchers, Dwight and Steven Hammond, who had been found guilty of arson on federal land. Yet, the protesters did not ask for the Hammonds' release; neither were the Hammonds willing to acknowledge any connection with the armed militants. Instead, the latter's purpose was for all federal land in Harney County to come under local control. Furthermore, while the Malheur occupiers tried to enlist the sympathy of the localsfor lack of their help-they ignored the fact that what they called "the people's facility" stood on land that had long been inhabited by Northern Paiutes, until the federal government removed them in 1872 and confined them to the Malheur Reservation. The latter was done away with seven years later, and its lands were added to the public domain, while the wildlife refuge was created in 1908 by President Theodore Roosevelt ("Malheur National Wildlife Refuge"). Despite the fact that the refuge harbors thousands of Native American artifacts, the militants were both oblivious and indifferent to this past, and "bulldozed through sacred burial grounds while trying to build a road" (Siegler, K., Oct. 27, 2016). When asked about Native Americans' rights to the land, occupation leaders offered mixed-if not conflicting-opinions. While Ryan Bundy was adamant that Native Americans had lost their claim to the land a long time ago, contending that "the current culture is the most important" (quoted in Keeler, J., 2017: 3), his brother Ammon confessed that he "really [didn't] know much about that," and that "they have rights as well" ("Press Conference...," Jan. 6, 2016). The confusion 
over who "the people" are was such that even the leaders of the occupation could not agree.

Yet, ultimately, since "[the] exact referents of 'the people' and 'the elite' don't define populism," one needs to analyze what defines it, i.e. "the conflictual relationship between the two-or in the case of right-wing populism the three" (Judis, J., 2016: 15). In other words, in order to fully assess the significance of each populist outburst at the regional and national level, it is necessary to look deeper into the agendas of the main actors and to evaluate the movements' impact.

\section{Agendas and achievements: from left-wing to right- wing populism}

The founding members of the People's Party ambitioned to give American voters an alternative to the traditional two-party contest opposing Republicans and Democrats. They presented candidates at the local, state, and national levels. Their wish to appeal to as large an electorate as possible and to unite American voters materialized in the Populist Party ticket to the 1892 Presidential election: James B. Weaver, running for President, was a former Union general from Iowa, while his running mate, James G. Field, was an ex-Confederate general from Virginia (Larson, R., 1986: 3).

However, the party's boldest move, besides its creation as a coalition of farmers and industrial workers brought together in time for the 1892 contest, was its platform. By the late 1870s, the country experienced industrial growth and economic prosperity. Yet farmers in the Plains and the South did not benefit from this progress. On the contrary, they faced more and more hardships: agricultural prices sharply decreased; a drought hit the Plains in the late 1880s; and railroad companies, which farmers depended on to send their produce throughout the country and abroad, took advantage of their monopoly status to raise their prices. As they formed Farmers' Alliances and organized cooperatives to try and have some control over prices, farmers became more politicized. The realization that they shared a common enemy with the Knights of Labor-the plutocracy-led them to unite. Among other things, the party's platform forcefully denounced corruption; opposed the gold standard, and requested the unlimited coinage of silver and gold; demanded an end to land speculation; and called for government control of railroads and a shorter work week.

Because they did not form as large a coalition as the 1890s Populists and did not constitute a third party that could have challenged the two established political forces of the country, the Sagebrush Rebels of the late 1970s were just that: rebels, who "renounce[d] and resist[ed] by force the authority of [their] government" (MerriamWebster). Even though they did not devise a platform nor a formalized set of demands, they did express specific grievances. Their number one goal was to force the federal government to turn over the control and management of public lands to the states in which they lay. Despite the fact that the dispute had to do with a very regional issue-it is estimated that the federal government owns more than $46 \%$ of the continental lands lying West of the $100^{\text {th }}$ meridian (Vincent, C., et al., March 3, 2017: i)-the Sagebrush Rebels managed to attract national attention, notably because their more general denunciation of the expansion of federal power appealed to Americans in other parts of the country. 
30 As James Morton Turner argues, their opposition did not stem so much from the 1960s-70s growing concerns over the environment as from the development of the role of the federal government in terms of environmental oversight and regulation, along with the impact of the latter on business and private property (Turner, J., 2009: 125). This enlargement of federal responsibilities in the realm of wilderness preservation resulted mostly from two landmark laws. In 1964, the Wilderness Act turned the United States into the first nation to define and protect wilderness areas through law, on a national scale. Most significantly, it gave Congress power to designate wilderness areas through the newly-created National Wilderness Preservation System. Twelve years later, the prerogatives of the federal government were again expanded with the passage of the Federal Land Policy and Management Act which, among other things, put an end to homesteading in the contiguous United States and placed the public domain under the supervision of the Bureau of Land Management. Consequently, by 1979 , the federal government owned about $87 \%$ of Nevada and more than $50 \%$ of Utah. Along with the economic crisis of the decade, this overwhelming federal presence in the US West explains the region's populist outburst of the late 1970s.

31 Land transfer was the number one demand of the "rebels." Beyond the denunciation of federal overreach, their populist rhetoric put forth two major arguments. A legal one rested on the "equal footing" doctrine, whereby a state entering the Union was admitted "on an equal footing with the original states" ("Doctrine of the Equality of States"). Westerners argued that, since the federal government owned so much land in western states, the latter were not equal with other states. Westerners also revived the states' rights argument. Senator Hatch's indictment of the BLM and "its bloated staff" contrasted with praise for local authorities:

The state manages its lands to satisfy essential human and environmental needs while making a responsible profit with which to meet other needs. In utter contrast, Washington cloaks its costly, self-perpetuating bureaucracy, with all its attendant rules and regulations, under the guise of an ill-defined 'public interest' which changes virtually daily according to the whims of those imposed upon us as its guardians (Hatch, O., 1979: 4A).

However, beyond these arguments, a financial issue was also central to the "rebellion." Nevada rancher Dean Rhoads contended that the land transfer the rebellion called for represented "the biggest land transaction on this continent since the Louisiana Purchase" (quoted in Boly, W., 1986: 19). Western politicians slyly bypassed the potential-if not inevitable-privatization of these lands, if transferred to the states, and swore by the benefits the people could reap from them, including "thousands of new jobs, millions of acres of land and billions of dollars in new profits [which] could accrue to the people of our Western states" (Senator Hatch quoted in Forrester, S., 1979: 27A). Ultimately, the rebellion was depicted as a moral crusade, the goal being to "return control of [their] destiny" to westerners (Hatch, O., 1979: 4A).

Considering the fact that the latest outburst of populism in the American West rests on the same arguments, it is tempting to conclude that the Sagebrush Rebellion did not achieve its goal. Attracting national attention was not an easy task in itself, and was accomplished only as a result of the "flurry of legislative activity" throughout the western states (Graf, W., 1990: 230). Yet, what truly emboldened and empowered the "rebels" was the political turn their fight took. In the summer of 1980, presidential candidate Ronald Reagan told a Republican crowd in Salt Lake City: "I happen to be one who cheers and supports the Sagebrush Rebellion. Count me in as a rebel" (quoted in 
Salisbury, D., 1980). A couple of weeks after his election, Reagan sent a telegram to the League for the Advancement of States Equal Rights (LASER, also known as the "Sagebrush Rebellion Conference"), to reassure westerners he had not forsaken them: "my administration will work to insure that the states have an equitable share of public lands and their natural resources" (Reagan, Nov. 20, 1980). Reagan's appointment of James Watt as Secretary of the Interior, a concrete illustration of Reagan's support, represented a major victory for the Sagebrush Rebels. Born in Wyoming, Watt was unapologetic in his anti-environmentalist stance, and soon devised a plan meant to undermine the national wilderness preservation system (Zaslowsky, D., and T. H. Watkins, 1994: 217). His policies ended up facing a lot of opposition in Congress. As for the "sagebrush" legislation, Senator Hatch's bill "died [a] quiet death," while the various western bills "collected dust in the archives" (Graf, W., 1990: 257). Watt's twoyear tenure as Secretary of the Interior was mired in controversy all along. If his appointment contributed to muting the rebellion, his resignation in late 1983 was the final blow that put it down for a while.

These mixed results draw attention to the nature of the rebels' demands or, rather, to their reasonableness. As Judis explains, "[t]he populists believe the demands [they make of the elite] are worthy and justified, but they don't believe the establishment will be willing to grant them." The Sagebrush Rebels' petition for land transfer to the states was not "ordinary" and, therefore, could not be "subject to immediate negotiation." It is this "clash between the people and the establishment" that defines westerners' populism (Judis, J., 2016: 16). Similarly, the demands listed in the People's Party's platform were bold and ambitioned to challenge the status quo. The "clash" their movement triggered partly paid off, as the Populists did get some encouraging results. For instance, the party scored a few electoral victories. In 1894, thirteen People's Party candidates were elected to the US Congress, while hundreds others successfully ran for state legislatures (Kazin, M., 1995: 42). These victories gave legitimacy to the Populists' fight and, therefore, heartened them. Most significantly, their demand for free silver was adopted by the Democrats in 1896. Even though Bryan lost the election to McKinley, the Democratic Party's adoption of the Populists' trademark measure was, in itself, a major victory.

However, the People's Party did not survive the 1896 election. Just as Watt's appointment was a win that sealed the fate of the Sagebrush Rebellion, the alliance with the Democrats-but, also, with Republicans in the South-represented a Pyrrhic victory for the People's Party. For, as Judis asserts, if the populists' demands "are granted in whole or even in part," then "the populist movement is likely to dissipate or to morph into a normal political party or candidacy" (Judis, J., 2016: 16). The failure of the People's Party led to a political realignment rather than the demise of Populism and, as Postel argues, it is important to pay heed to the "impetus that [Populism] provided for a wave of reform that carried into the new century" (Postel, C., 2007: 22).

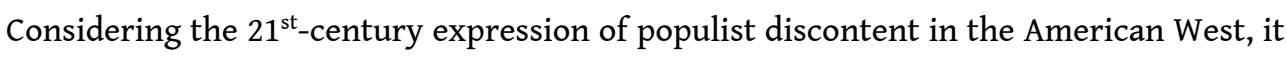
is fair to say that the Sagebrush Rebellion did not disappear completely, either. Even though western farmers and ranchers' anger abated for a while, it was revived in the 1990s under the guise of the "wise use movement." The same issues of private property rights, public land use and economic exploitation resurfaced, with resource extraction industries pushing for deregulation. The long-simmering dispute exploded again in the 2010s, at both the grassroots and political levels. In 2012, Utah adopted a Transfer of 
Public Lands Act which set a deadline for the federal government to transfer to Utah control and management of the federal lands situated within the state's borders. The same animosity towards the federal government pervaded Utah's lawmakers' defense of the legislation, and their justification for the law was clothed in the same populist rhetoric heard during the heyday of the Sagebrush Rebellion. Utah Representative Ken Ivory, who introduced the bill in the Utah House, thus claimed: "This is our time to write the history of what will happen in our state. [...] This is our time to look not to the next election, but to the next generation" (Gehrke, R., March 3, 2012). As evidenced by the Bunkerville (NV) standoff and the Malheur Wildlife Refuge (OR) occupation, rural westerners also gave vent to their frustration, albeit in a less moderate way.

In their analysis of right-wing populism, Chip Berlet and Matthew Lyons contend that "[o]ne of the staples of repressive and right-wing populist ideology has been producerism, a doctrine that champions the so-called producers in society against both 'unproductive' elites and subordinate groups defined as lazy and immoral" (Berlet, C., and M. Lyons, 2000: 6). In other words, right-wing populism differs from its left-wing counterpart in that "the people" are opposed not just to the elite but, also, to a third group, an "out group" consisting of "immigrants, Islamists, [or] African American militants" among other examples (Judis, J., 2016: 14).

Berlet and Lyons break down right-wing populists into three groups: advocates of a "get the government off my back" ideology, xenophobes, and ultra-conservative Christian evangelicals (Berlet, C., and M. Lyons, 2000: 347-8). Their fight against the federal government-these "modern-day conquerors, just self-appointed predators" (Bundy, A., Sept. 11, 2015)-puts the Bundys in the first of these categories. They constantly swear by the Constitution-a pocket version of which they always carrybecause, to them, it protects states' rights over the federal government. And, indeed, the Constitution is the "sole guiding force" (Trenbeath, E., July 2, 2014) of the rightwing and libertarian extremists who came from all over the United States and took part in the Bunkerville standoff: Oath Keepers, Three Percenters, Sovereign Citizens, and other members of the so-called "Patriot Movement." Emboldened and legitimized by the retreat of the federal agents at the Bundy Ranch in Nevada, militia members joined the Bundy sons again when they decided to occupy the Malheur National Wildlife Refuge in January 2016.

Obviously, these latest outbursts of western populism were more than "ranchers' wars." Ammon Bundy's claim that "the land titles need to be transferred back to the people" ("Press conference...," Jan. 6, 2016) and the overall issue of public lands were just the tip of the iceberg. Underlying this theme were topics widely discussed in the Patriot movement, as listed by Berlet:

government abuse of power; fears about globalism and sovereignty; economic distress (real, relative, and anticipated); apocalyptic fears of conspiracy and tyranny from above; male identity crisis, backlash against the social liberation movements of the 1960s and 1970s, and more (Berlet, C., and M. Lyons, 2000: 289).

The heavily armed militants, whether at the Bunkerville standoff or the refuge occupation, were adamant about defending their gun rights: "We understand that in order to truly express our First amendment rights, we have to have our Second amendment rights, and that's why the Founders gave them to us, or at least that's why the Founders protected them in the Constitution" ("Armed Oregon Militiamen...," Jan. $3,2016)$. 
41 Furthermore, these groups are also known for their racism, further matching Berlet and Lyons' categorization. Despite its “[lacking] the open appeals to white racial purity" (Sunshine, S., 2016: 4) which characterized the 1990s militias, today's "movement radiates an unspoken White nationalism" (ibid., 28), albeit with variations. Xenophobia, for instance, tends to characterize the Three Percenters, while the Patriot Movement is divided between white supremacists and white separatists (ibid., 144). The very concept of "citizenship" is discussed and debated in racial terms, pitting "sovereign white Christian men" against "Fourteenth Amendment citizens" (Zeskind, L., 2009: 81). Cliven Bundy epitomizes the dual racist ideology and "producerist" thinking underlying right-wing populism. Following the armed standoff that opposed him to the Bureau of Land Management, the rancher declared: "I want to tell you one more thing I know about the Negro: I've often wondered, are they better off as slaves, picking cotton, having family lives and doing things, or are they better off under government subsidies?" (CBS This Morning, April 25, 2014). Bundy and the western Patriot movement see farmers, loggers and ranchers as producers, the federal government as the elite, and African Americans and other minorities as "lazy and immoral." 4

These outbursts seem to have quieted down a bit since the Oregon occupation. Even though the populists' demands were not "granted in whole or even in part," it is important to acknowledge that the militants did score significant victories when the courts proved to be particularly lenient towards them: in October 2016, the Bundy brothers were acquitted of all charges in the case of the Oregon occupation, and in early 2018, all charges against Cliven Bundy and his sons were dismissed regarding the Bunkerville standoff (Bernstein, M., Jan. 8, 2017). Added to President Trump's pardon of the Hammonds in July 2018, these decisions seem to have legitimized the rural westerners' fight and given them signs of encouragement. Just as Trump's indictment of the Antiquities Act and his administration's simultaneous shrinking of Bears Ears National Monument pandered to western politicians' populist call for greater state responsibility, the gesture of "the people's President" towards the Hammonds could certainly be interpreted as a sign that the $21^{\text {st }}$-century rebels have a friend in the White House (Ryan Bundy for Nevada Governor).

\section{Conclusion}

In The Age of Reform, Richard Hofstadter depicted 1890s farmers as having a "dual character": a "soft side," according to which they were the victims of the march of progress, and a "hard side," that made them proponents of "agricultural improvement, business methods, and pressure politics." Hofstadter contended that the Populist rhetoric stemmed from farmers' "soft side," that is to say from their attachment to the agrarian myth (Hofstadter, R., 1955: 47). Twenty years later, Lawrence Goodwyn analyzed Populism as the expression of farmers' resistance to modernity, and to "the corporate state and the creed of progress it put forward" (Goodwyn, L., 1978: xxi). In many ways, it is tempting to read the latest episodes of western populism through Hofstadter's and Goodwyn's lens, and to conclude that the outbursts of western populism demonstrate rural westerners' conservatism.

Yet, as Charles Postel has established, late $19^{\text {th }}$-century Populists were "modern people," in the sense that they "understood that the transformations they sought 
required the uprooting of rural ignorance, inertia, and force of habit" (Postel, C., 2007: 9). Even though one could see the Bundy family and their supporters as cowboys clinging to a way of life that has become irrelevant in a predominantly urban West, Postel's argument that the 1890s Populists "shape[d] the weapons of protest out of the modern materials of technological, organizational, and ideological innovation" (ibid., viii) could well apply to the modern-day western populists. Their use of social media to promote their cause, spread their political messages, call on supporters to join their fight, and appeal to Americans' generosity to help them pay their legal fees makes them fundamentally modern. At the same time, in spite of the image of rugged individualism that the Bundys want to advertise, it is the region's relationship with the federal government that has allowed the West to develop and even thrive.

Even though the two latest episodes do not match Postel's characterization of $1890 \mathrm{~s}$ Populism as "a national movement with a national vision" (ibid., 14), the three of them confirm Kazin's contention that "populism in the United States has made the unique claim that the powers that be are transgressing the nation's founding creed, which every permanent resident should honor" (Kazin, M., 1995: 2). Given the scope of the "People for Constitutional Freedom," it would be an overstatement to claim that the movement "function[s] as [a] warning sign of a political crisis" (Judis, J., 2016: 16). However, the movement did emerge at a time "when people [saw] the prevailing political norms-put forward, preserved and defended by the leading segments in the country-as being at odds with their own hopes, fears, and concerns" (ibid., 17). It certainly is no coincidence that the radicalization of western populism took place just as Trump and Sanders were gaining in visibility, signaling that "the standard worldview [was] breaking down" (ibid.).

\section{BIBLIOGRAPHY}

Allen, Jonathan, and Jim Urquhart, "Sympathy for Jailed Ranchers, Anger at Occupiers in Oregon Town,” Reuters, January 4, 2016, https://www.reuters.com/article/us-oregon-militiaidUSKBNOUI1DC20160105, visited January 25, 2019.

“Armed Oregon Militiamen Speak Out from Occupied Refuge," ABC News, January 3, 2016, http:// abcn.ws/1RlkuhG, visited January 25, 2019.

Berlet, Chip, and Matthew N. Lyons, Right-Wing Populism in America. Too Close for Comfort, New York, The Guilford Press, 2000.

Bernstein, Maxine, "Cliven Bundy standoff case thrown out in another stunning blow to government," The Oregonian, January 8, 2017, http://www.oregonlive.com/oregon-standoff/ 2018/01/cliven_bundy_standoff_case_thr.html, visited January 25, 2019.

Boly, William, “The Sagebrush Rebels," New West, November 3, 1980, p. 17-27.

Boone, Rebecca, “Oregon Tribe: Armed Group ‘Desecrating' Their Land,” East Oregonian, January 6, 2016, https://www.eastoregonian.com/news/northwest/oregon-tribe-armed-group-desecratingtheir-land/article_f462ac81-cbd3-50d3-bfa4-f7621774a228.html, visited January 25, 2019. 
Bundy, Ammon, “What authority are they acting on?," Sept. 11, 2015, https://www.youtube.com/ watch?time_continue=8\&v=FpaL0qWColo, visited January 25, 2019.

Bundy Ranch, January 2, 2016, https://www.facebook.com/bundyranch/videos/ 938588846217924/, visited January 25, 2019.

Cawley, R. McGreggor, Federal Land, Western Anger. The Sagebrush Rebellion and Environmental Politics, Lawrence, University Press of Kansas, 1993.

CBS This Morning, April 25, 2014, https://www.youtube.com/watch?v=laq1I4kmk7E, visited January 25, 2019.

"Doctrine of the Equality of States;" Section 3 - clause 1," https://law.justia.com/constitution/ us/article-4/15-doctrine-of-the-equality-of-states.html, visited January 25, 2019.

Forrester, Steve, "Sagebrush Rebellion Losing on Capitol Hill," Eugene Register-Guard, Dec. 9, 1979, p. 27A.

Gates, Paul Wallace, History of Public Land Law Development. Written for the Public Land Law Review Commission, Washington, D.C., 1968.

Gehrke, Robert, "Utah Fires Up New Sagebrush Rebellion,” The Salt Lake Tribune, March 3, 2012, https://archive.sltrib.com/article.php?id=53636377\&itype=CMSID, visited January 25, 2019.

Goodwyn, Lawrence, "Populist Dreams and Negro Rights: East Texas as a Case Study," The American Historical Review 76-5, Dec. 1971, p. 1435-1456.

Goodwyn, Lawrence, The Populist Moment: A Short History of the Agrarian Revolt in America, New York, Oxford University Press, 1978.

Graf, William L., Wilderness Preservation and the Sagebrush Rebellions, Savage, MD: Rowman and Littlefield Publishers, 1990.

Hatch, Orrin, “'Sagebrush Rebellion' Is No Measly Brush Fire,” Deseret News, Sept. 26, 1979, p. 4A.

Hicks, John D., Populist Revolt. A History of the Farmers' Alliance and the People's Party, Saint Paul, University of Minnesota Press, 1931.

Hofstadter, Richard, The Age of Reform. From Bryan to F.D.R., New York, Knopf, 1955.

Johnson, Joshua, “Your Land. Our Land. Who Owns the West?," The 1A, February 21, 2017, https:// the1a.org/shows/2017-02-21/public-land, visited January 25, 2019.

Judis, John B., The Populist Explosion. How the Great Recession Transformed American and European Politics, New York, Columbia Global Reports, 2016.

Kazin, Michael, The Populist Persuasion. An American History, New York, BasicBooks, 1995.

Keeler, Jacqueline, Edge of Morning. Native Voices Speak for the Bears Ears, Salt Lake City, Torrey House Press, 2017.

Larson, Robert W., Populism in the Mountain West, Albuquerque, University of New Mexico Press, 1986.

Levin, Sam, "Cliven Bundy Rebukes Trump Over Attack on Migrants: 'We Should Have a Heart', ' The Guardian, November 29, 2018, https://www.theguardian.com/us-news/2018/nov/28/clivenammon-bundy-criticizes-trump-immigration-border-wall, visited January 25, 2019.

Lincoln, Abraham, Gettysburg Address, Nov. 19, 1863, http://www.abrahamlincolnonline.org/ lincoln/speeches/gettysburg.htm, visited January 25, 2019. 
"Malheur National Wildlife Refuge," The Oregon Encyclopedia, https://oregonencyclopedia.org/ articles/malheur_national_wildlife_refuge/, visited January 25, 2019.

“Militant leader explains intentions on Oregon refuge takeover," The Oregonian, January 3, 2016, https://www.youtube.com/watch?v=eb80q83Uzb0, visited January 25, 2019.

Mudde, Cas, and Cristóbal Rovira Kaltwasser, Populism: A Very Short Introduction, Oxford, Oxford University Press, 2017.

National People's Party Platform, adopted at Omaha, NE, July 4, 1892, http://

teachingamericanhistory.org/library/document/national-peoples-party-platform-adopted-atomaha-neb-july-4-1892/, visited January 25, 2019.

Nevada Assembly Bill 413, introduced February 15, 1979.

Ostler, Jeffrey, Prairie Populism. The Fate of Agrarian Radicalism in Kansas, Nebraska, and Iowa, 1880-1892, Lawrence, University Press of Kansas, 1993.

Postel, Charles, The Populist Vision, New York, Oxford University Press, 2007.

"Press Conference at Wildlife Refuge Headquarters," The Oregonian, January 6, 2016, https:// www.youtube.com/watch?v=vwQ-jHg00Ns, visited January 25, 2019.

Reagan, Ronald, “Telegram from Ronald Reagan to Sagebrush Rebellion Conference," Nov. 20, 1980, http://archive.oah.org/special-issues/teaching/2009_06/sources/ex5src6_sr287.html, visited January 25, 2019.

Ryan Bundy for Nevada Governor, https://www.governorbundy.com/, visited November 2, 2018.

S.1680 - Western Lands Distribution and Regional Equalization Act of $1979,96^{\text {th }}$ Congress (1979-1980), introduced August 3, 1979, https://www.congress.gov/bill/96th-congress/senatebill/1680, visited January 25, 2019.

Siegler, Kirk, “Oregon Occupation Unites Native American Tribes To Save Their Land," NPR, October 27, 2016, https://www.npr.org/2016/10/27/499575873/oregon-occupation-unitesnative-american-tribes-to-save-their-land , visited January 25, 2019.

Sunshine, Spencer, “Up in Arms: A Guide to Oregon's Patriot Movement," Rural Organizing Project and Political Research Associates, 2016, http://www.rop.org/wp-content/uploads/Up-inArms_Report_PDF-1.pdf

“The Sagebrush Rebellion," US News and World Report, Dec. 1, 1980, https://web.archive.org/web/ 20110720111115/http://www2.vcdh.virginia.edu/PVCC/mbase/docs/sagebrush.html, visited January 25, 2019.

Trenbeath, Eric W., "Wild Utah," Salt Lake City Weekly, July 2, 2014, https://www.cityweekly.net/ utah/wild-utah/Content?oid=2428844, visited January 25, 2019.

Turner, James Morton, “'The Specter of Environmentalism': Wilderness, Environmental Politics, and the Evolution of the New Right," The Journal of American History, June 2009, p. 123-148.

Vincent, Carol Hardy, Laura A. Hanson, and Carla N. Argueta, "Federal Land Ownership: Overview and Data," Congressional Research Service, March 3, 2017.

Zaslowsky, Dyan, and T. H. Watkins, These American Lands. Parks, Wilderness, and the Public Lands, Washington, D.C., Covelo, CA.: Island Press, 1994. 


\section{NOTES}

1. As this analysis will show, the later periods of populist agitation have not had the same scope and impact and, therefore, do not carry the same historical significance as the late- $19^{\text {th }}$ century movement.

2. Paul Gates explains how, starting in 1878, miners and loggers united with railroad companies to denounce Secretary of the Interior Carl Schurz's policy targeting unlicensed and wasteful tree cutting on public lands. The Department of the Interior was soon accused "of resorting to arbitrary action against the small, defenseless man, of taking steps that threatened the very basis of existence of thousands of people in the South, the Lake States, the mining communities, and the rapidly growing lumber industry on the West Coast" (Gates, P. W., 1968: 549).

3. "Sagebrush" refers to the vegetation of much of the land lying within the borders of Nevada, one of the most arid states west of the $100^{\text {th }}$ meridian. Despite its low yield, the land is considered as suitable for grazing. The expression "Sagebrush Rebellion" was meant to be derogatory when it was first used by journalists; yet proponents of the movement "quickly adopted it as their rallying cry" (Cawley, R., 1993: 14).

4. However, Ammon Bundy, Cliven's son, criticized Donald Trump's xenophobic attitude toward a migrant caravan in late 2018. This stance put him at odds with the Patriot movement and with his own father who, wondering if the migrants may have been paid to be in the caravan, seemed to subscribe to conspiracy theories (Levin, S., Nov. 29, 2018).

\section{ABSTRACTS}

This article aims to appraise the populist strain that has characterized the American West since the late $19^{\text {th }}$ century. Populism, as a political movement, was born in the South and West of the United States. This "prairie populism" allowed the People's party to score quite a few electoral victories in the 1890s. While the party's influence waned rapidly, outbursts of populism have animated the West since then. In spite of the centrality of the "people"-and its opposition with "the elite"-as the major definitional element that binds these various expressions of populism together, $21^{\text {st }}$-century western populism has little in common with its late $19^{\text {th }}$-century counterpart. The purpose of this essay is to analyze the evolution of western populism, from the People's party to the late 1970s Sagebrush Rebellion and the People for Constitutional Freedom. Attention is paid to each movement's emphasis on the "people" as the element at the core of their rhetoric. In addition, this study reveals how this key element has evolved throughout the $20^{\text {th }}$ century, and in what ways today's populism seeks to defend the interests of a much more limited group. Finally, a close reading of the goals and achievements of each movement offers a better understanding of this evolution from left-wing to right-wing populism.

Cet article a pour but d'étudier la tendance populiste qui caractérise l'Ouest américain depuis la fin du XIX ${ }^{e}$ siècle. Le Populisme, en tant que mouvement politique, est né dans le Sud et l'Ouest des États-Unis, et son importance ne saurait être sous-estimée, eu égard aux victoires électorales remportées par le «Parti du Peuple» dans les années 1890. Bien que l'influence du parti ait décliné après quelques années seulement, la région fut régulièrement le théâtre de résurgences populistes par la suite. La centralité du " peuple », de même que l'opposition entre le "peuple » et l'«élite», constituent les invariants de ces diverses explosions populistes. Cependant, son 
expression la plus récente n'a que peu de points communs avec son équivalent de la fin du XIX siècle. Le but de cet article est d'analyser l'évolution du populisme tel qu'il s'exprime dans l'Ouest américain, du « Parti du Peuple » au « Peuple pour la liberté constitutionnelle », en passant par la «Sagebrush Rebellion » de la fin des années 1970. Une attention particulière est portée à la façon dont chaque mouvement situe le «peuple » au cœur de sa rhétorique. De plus, cette étude révèle comment cet élément central a évolué tout au long $\mathrm{du} \mathrm{xx}^{\mathrm{e}}$ siècle et de quelle manière le populisme actuel cherche à défendre les intérêts d'un groupe beaucoup plus restreint. Enfin, une lecture approfondie des objectifs et de l'impact de chaque mouvement permet de mieux comprendre cette évolution d'un populisme de gauche vers un populisme de droite.

Este artículo tiene por objetivo evaluar la tendencia populista que ha caracterizado el oeste estadounidense desde finales del siglo XIX. El populismo nació como movimiento político en el sur y el oeste de los Estados Unidos. Este “populismo de pradera”, le permitió al Partido Popular conseguir bastantes victorias electorales en la década de 1890. Aun cuando la influencia del partido disminuyera después de unos pocos años, resurgencias populistas no pararon de brotar en la zona desde aquel entonces. Sin embargo, a pesar de la centralidad del "pueblo" y de la oposición entre "pueblo" y "élite", como elemento principal de la definición de estas diversas expresiones del populismo, dicho populismo occidental del siglo XXI tiene poco en común con su contraparte de finales del siglo XIX. El propósito de este artículo es analizar la evolución del populismo del Oeste de los Estados Unidos, desde el "Partido Popular" hasta el "Pueblo por la Libertad Constitucional", pasando por la "Sagebrush Rebellion" de finales de los años setenta. El artículo enfatiza cómo cada movimiento pone el "pueblo" al centro de su retórica. Además, este estudio revela la evolución de este elemento esencial a lo largo del siglo xx, y cómo el populismo actual trata de defender los intereses de un grupo mucho más limitado. Finalmente, una lectura pormenorizada de los objetivos y logros de cada movimiento permite entender mejor esta evolución desde un populismo de izquierda a uno de derecha.

\section{INDEX}

Mots-clés: Ouest américain, Parti du Peuple, Sagebrush Rebellion, Peuple pour la liberté constitutionnelle, populisme de gauche, populisme de droite

Keywords: American West, People's party, Sagebrush Rebellion, People for Constitutional Freedom, left-wing populism, right-wing populism

Palabras claves: Oeste americano, Partido Popular, Sagebrush Rebellion, Pueblo por la Libertad Constitucional, populismo de izquierda, populismo de derecha

\section{AUTHOR}

\section{NATHALIE MASSIP}

Nathalie Massip is associate professor of American studies at Université Côte d'Azur. She has published on the New Western History, public history, and representations of the American West. Her research currently focuses on public land policy, as well as $21^{\text {st }}$-century issues in land management in the American West. She has recently contributed a chapter to the book The Interior Borderlands: Regional Identity in the Midwest and Great Plains to be published by the Center for Western Studies Press. Nathalie.MASSIP@univ-cotedazur.fr 